\title{
Contralateral Prophylactic Mastectomy in Patients with Breast Cancer
}

\author{
Aniela Nodițit ${ }^{1,2}$, George Caragheorghe ${ }^{1,2^{*}}$, Smaranda Stoleru' ${ }^{1}$, Alexandru Blidaru ${ }^{1,2}$, Cristian Ioan Bordea ${ }^{1,2}$ \\ 'University of Medicine and Pharmacy "Carol Davila", Bucharest, Romania \\ ${ }^{2}$ Institute of Oncology "Prof. Dr. Al. Trestioreanu”, Department of Surgical Oncology, Bucharest, Romania
}

${ }^{*}$ Corresponding author: George Caragheorghe, MD University of Medicine and Pharmacy "Carol Davila", Bucharest

"Prof. Dr. Al. Trestioreanu" Institute of Oncology, Department of Surgical Oncology, Bucharest

E-mail: george.caragheorghe@gmail.com

\section{Rezumat}

Mastectomia profilactică contralaterală la pacientele cu cancer mamar

Introducere: Numărul de mastectomii contralaterale profilactice a crescut în ultimii ani. Principalele motive sunt: testarea genetică, disponibilitatea reconstructiei mamare, utilizarea mai frecventă preoperator a IRM-ului mamar, îmbunătățirea rezultatelor estetice postoperatorii şi rambursarea reconstrucției mamare. Scopul studiului a fost să analizeze indicația mastectomiei contralaterale profilactice, evoluția acesteia şi tehnicile chirurgicale utilizate pentru acest tip de intervenție chirurgicală.

Materiale şi Metode: În acest studiu prospectiv au fost înscrise paciente cu cancer mamar unilateral pentru care tratamentul conservator mamar nu a fost o opțiune şi la care s-a efectuat mastectomie contralaterală profilactică concomitent cu mastectomia terapeutică, folosind diferite tipuri de tehnici chirurgicale, urmate de reconstrucție imediată a sânilor folosind materiale aloplastice.

Rezultate: Am analizat un număr de 45 de paciente cu neoplasm mamar unilateral cu mastectomie terapeutică şi mastectomie contralaterală profilactică urmate de reconstrucție mamară imediată în perioada ianuarie 2015-decembrie 2020. Vârsta medie a fost de 43,5 ani, 66,44\% dintre paciente au prezentat cancer mamar în stadiul I şi II, iar $22,22 \%$ cancer mamar triplu negativ. Indicațiile pentru mastectomie contralaterală profilactică au fost: mutație patogenă BRCA sau a altor gene asociate cu risc crescut de cancer mamar, antecedente heredo-colaterale pentru cancer mamar, leziuni suspecte decelate de IRM-ul mamar, microcalcificări extinse, sâni denşi şi anxietate extremă.

Concluzii: A fost observată o creştere a ratei de mastectomie bilaterală pentru cancer mamar unilateral. Disponibilitatea 
reconstrucției mamare imediate şi rambursarea acesteia joacă un rol important în dorința pacientelor de a efectua mastectomie contralaterală profilactică. Factorii asociați mastectomiei contralaterale profilactice includ: vârstă tânără, mutație patogenă BRCA, antecedente familiale semnificative şi cancer mamar triplu negativ. A fost înregistrat un număr redus de complicații postoperatorii imediate. Mastectomia profilactică contralaterală este o opțiune validă pentru a reduce riscul de apariție a cancerului mamar contralateral şi pentru a obține un rezultat estetic bun în cazul pacientelor cu cancer mamar unilateral cu risc crescut de cancer mamar contralateral.

Cuvinte cheie: cancer mamar, mastectomie profilactică contralaterală, BRCA, reconstrucție mamară

\section{Abstract}

Introduction: The rate of contralateral prophylactic mastectomy (CPM) increased within the recent years. The main reasons are: genetic testing, availability of breast reconstruction, more often use of preoperative breast MRI, improvement of postoperative aesthetic results and reimbursement of breast reconstruction. The purpose of this study was to analyze the indication of CPM, it's evolution and the surgical techniques used for this type of surgery.

Materials and Methods: This prospective study enrolled patients with unilateral breast cancer for which conservative treatment was not an option and underwent CPM concomitant with therapeutic mastectomy, using different techniques, followed by immediate breast reconstruction using alloplastic materials.

Results:A total of 45 patients with unilateral breast cancer underwent therapeutic mastectomy and CPM followed by immediate breast reconstruction, between January 2015-December 2020. The mean age was 43.5 years, $64,44 \%$ patients had stage I and II breast cancer and $22,22 \%$ were triplenegative. The indications for CPM were: pathogenic mutation of BRCA or of other genes associated with high risk of breast cancer, strong family history, suspicious findings on breast MRI, extended micro-calcifications, dense breasts, and extreme anxiety.

Conclusions: A growing rate of bilateral mastectomy for unilateral breast cancer was observed. Availability of immediate breast reconstruction and reimbursement plays an important role for patients in choosing CPM. Factors associated with CPM include: young age, pathogenic BRCA mutation, significant family history and triple-negative disease. The rate of immediate postoperative complications was low. CPM is a valid option to reduce the risk of contralateral breast cancer and to achieve a good aesthetic outcome for patients with unilateral breast cancer with high risk of contralateral breast cancer.

Key words: breast cancer, contralateral prophylactic mastectomy, BRCA, breast reconstruction

\section{Introduction}

The number of CPM is increasing in patients with unilateral breast cancer. There are multiple reasons for this. As genetic testing to identify hereditary susceptibility for breast cancer becomes more common and available, interest in prophylactic mastectomy is growing (1). The use of preoperative breast MRI significantly raises the rate as well. Improved reconstructive techniques and the desire to achieve breast symmetry are contributing to the decision of CPM (2).

The use of CPM more than doubled within the recent years (2). The increasing use of this type of surgery is as well patient driven, because of fear of a contralateral breast cancer (2). The intense anxiety caused by the news of 
having breast cancer and the tendency to overestimate the risk for a contralateral breast cancer affects decision-making (2). CPM is often chosen by patients to eliminate the anxiety and stress of surveillance and avoid what they perceive as an inevitable diagnosis of contralateral breast cancer (2). Another reason for choosing this type of surgery is the availability of breast reconstruction, improvement of postoperative aesthetic results and reimbursement of breast reconstruction.

The purpose of our study was to analyze the indication of CPM, it's evolution and the surgical techniques used for this type of surgery.

\section{Materials and Methods}

\section{Population Study}

A prospective analysis was conducted for patients who underwent bilateral mastectomy followed by immediate breast reconstruction for unilateral breast cancer performed by the same surgical team in the Institute of Oncology "Prof. Dr. Al. Trestioreanu" Bucharest and private medical centers between January 2015 - December 2020.

The study included patients with unilateral breast cancer for which conservative treatment was not an option. Therapeutic mastectomy was performed because of extensive ductal carcinoma "in situ", unfavorable tumor/breast ratio even after neoadjuvant, multifocality/ multicentricity, disseminated micro-calcifications, impossibility of postoperative radiotherapy or patient's will. Concomitant CPM was performed for pathogenic mutation of BRCA or of other genes associated with high risk of breast cancer (PALB2, CHEK2), strong family history of breast cancer, gigantomastia, difficult surveillance because of dense breast, diffuse micro-calcifications and for extreme anxiety related to the risk of contralateral breast cancer.

\section{Types of Surgeries}

The patients underwent therapeutic mastec- tomy and CPM, followed by immediate breast reconstruction using different techniques. Axillary surgery was represented by: sentinel lymph node biopsy or axillary dissection. Depending on the characteristic of the disease, localization of the tumor, response after neoadjuvant treatment, status of the sentinel lymph node and anatomical features of the patient (BMI, breasts size and shape) oncoplastic techniques were used to improve the aesthetic outcome.

In case of mastectomy followed by breast reconstruction, taking into account the location of the tumor, it's relation to the nipple-areola complex and the result of the intraoperative histopathologic examination of the retro-areolar tissue, skin-sparing or nipple-sparing mastectomy was chosen. In case of patients with large, ptotic breasts a skin-reducing mastectomy was performed.

For immediate breast reconstruction tissue expanders and different types of silicon implants were used: round or anatomical, smooth or textured, Becker and B-lite. Tissue expanders were placed submuscular and the implants were placed partially under the pectoralis major muscle and covered on the inferior part by synthetic mesh, accellular dermal matrix (ADM) or de-epithelialized skin-flap and epipectoral.

\section{Results}

Between January 2015 - December 2020, from 1849 interventions for breast cancer 85 $(4.60 \%)$ were bilateral surgeries. 35 (1.89\%) patients had bilateral breast cancer and underwent bilateral mastectomy and 5 $(0.27 \%)$ patients with unilateral breast cancer underwent therapeutic mastectomy and CPM.

$45(2.43 \%)$ patients with unilateral breast cancer underwent therapeutic mastectomy and CPM followed by immediate breast reconstruction. These patients are the population study analyzed.

The number of patients undergoing CPM was increasing with each passing year (Table 1).

The indications for CPM were: pathogenic 
Table 1. Number of patients undergoing CPM

\begin{tabular}{cc}
\hline Year & Patients \\
\hline 2015 & 2 \\
\hline 2016 & 5 \\
\hline 2017 & 7 \\
\hline 2018 & 11 \\
\hline 2019 & 15 \\
\hline 2020 & 5 \\
\hline
\end{tabular}

mutation of BRCA or of other genes associated with high risk of breast cancer, strong family history, suspicious findings on breast MRI, extended micro-calcifications, dense breasts, and extreme anxiety. Contralateral mastectomy was also performed in patients with gigantomastia for symmetry purposes.

CPM was performed for 25 (55.55\%) patients with pathogenic BRCA mutations (Fig. I) and $3(6.66 \%)$ patients with pathogenic mutation of other genes associated with high risk of breast cancer (PALB2, CHEK2) (Fig. 2).

There were $2(4.44 \%)$ patients with strong family history, who did not undergo genetic testing and underwent CPM.

For $11(24.44 \%)$ patients with gigantomastia, from which 4 patients had strong family history and no pathogenic mutations, CPM was an option for symmetry and risk reduction purposes.

For other $3(6.66 \%)$ patients the indication for CMP was: $1(2.22 \%)$ case for dense breasts, $1(2.22 \%)$ case for extended micro-calcifications and $1(2.22 \%)$ case for numerous contralateral suspicious foci on the preoperative breast MRI.

One $(2.22 \%)$ patient had extreme anxiety related to the risk of contralateral breast cancer that did not respond to psychological and psychiatric support strategies and underwent CPM. The youngest patient was 23 years old, the oldest one was 67 and the mean age was 43.5 years.

According to TNM classification 13 $(28.88 \%)$ patients were stage I, $16(35.55 \%)$ stage II, $4(8.88 \%)$ were stage III A and 2 (4.44\%) stage III B.
Figure 1. BRCA1 pathogenic mutation result

\begin{tabular}{|c|c|c|c|}
\hline \multicolumn{4}{|c|}{ Sample Information } \\
\hline Name: & & Date Received: & \\
\hline Father's Name: & & Date of Report: & \\
\hline Date of Birth: & & Req. Physician: & \\
\hline Patient Location: & & Report No: & \\
\hline Material: & WHOLE PERIPHERAL BLOOD & Sample Acceptability: & PASS \\
\hline
\end{tabular}

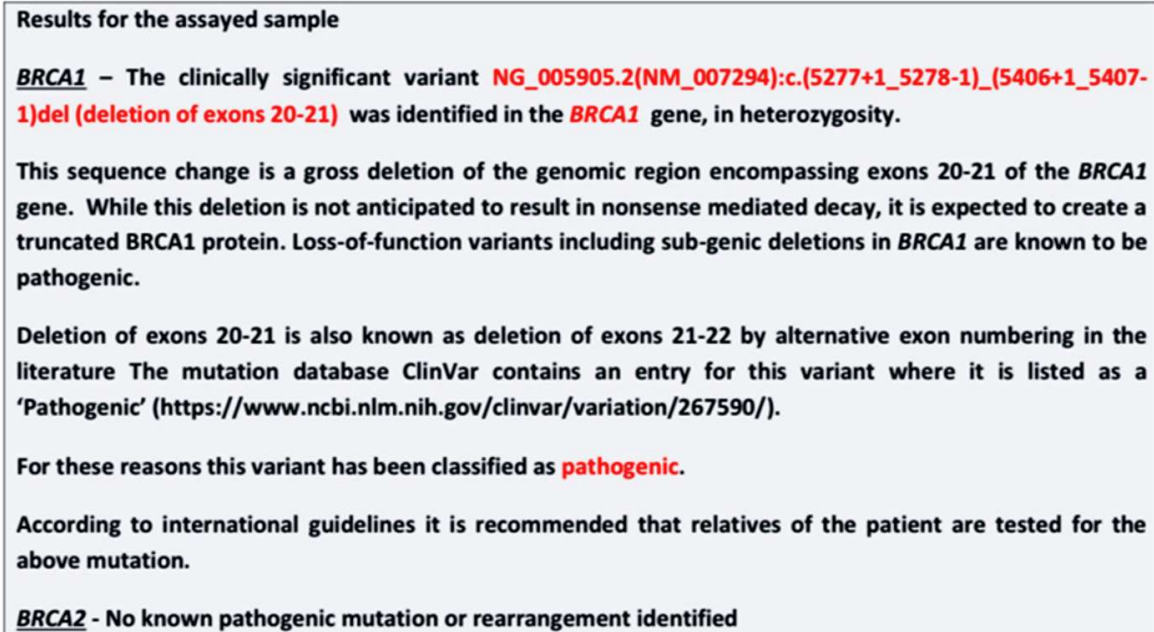

BRCA2 - No known pathogenic mutation or rearrangement identified 
Figure 2. Non-BRCA pathogenic result

\section{SAMPLE INFORMATION}

\begin{tabular}{|c|c|c|c|}
\hline Name: & & Date Received: & \\
\hline Medical ID: & & Date of Report: & \\
\hline Date of Birth & & Req. Physician: & \\
\hline Location: & & Barcode: & \\
\hline Material: & WHOLE PERIPHERAL BLOOD & Sample acceptability: & Pass \\
\hline
\end{tabular}

PATHOGENIC VARIANT IDENTIFIED

\begin{tabular}{|r|l|c|c|}
\hline Gene & \multicolumn{1}{|c|}{ Variant } & \multicolumn{1}{|c|}{ Clinical Significance } & Zygosity \\
\hline PALB2 & $\begin{array}{l}\text { NM_024675:c.93dupA, } \\
\text { P.(Leu32Thrfs*11) }\end{array}$ & Pathogenic-Clinically significant variant & Heterozygous \\
\hline
\end{tabular}

Note: "CLINICALLY SIGNIFICANT" as defined in this report, is a genetic change that is associated with the potential to after medical intervention

\begin{tabular}{|c|c|c|c|c|}
\hline \multicolumn{5}{|c|}{ SAMPLE INFORMATION } \\
\hline \multirow{2}{*}{\multicolumn{2}{|c|}{$\begin{array}{l}\text { Name: } \\
\text { Medical ID: }\end{array}$}} & \multicolumn{3}{|l|}{ Date Received: } \\
\hline & \multicolumn{4}{|c|}{ Date of Report: } \\
\hline Date of Birth: & \multicolumn{4}{|c|}{ Req. Physician: } \\
\hline Location: & \multicolumn{4}{|c|}{ Barcode: } \\
\hline \multicolumn{2}{|r|}{ WHOLE PERIPHERAL BLOOD } & Sample acceptability: & \multicolumn{2}{|l|}{ Pass } \\
\hline \multicolumn{5}{|c|}{ HerediGENE: Hereditary Cancer Panel by Next Generation Sequencing } \\
\hline \multicolumn{5}{|l|}{ Result } \\
\hline \multicolumn{5}{|c|}{ PATHOGENIC VARIANT IDENTIFIED } \\
\hline Gene & Variant & \multicolumn{2}{|c|}{ Clinical Significance } & Zygosity \\
\hline CHEK2 & $\begin{array}{l}\text { NM_007194:c.(908+1_909. } \\
\text { 1)_(1095+1_1096-1) }\end{array}$ & \multicolumn{2}{|c|}{ Pathogenic variant in a moderate risk cancer gene } & Heterozygous \\
\hline MLH1 & NM_000249:c.37G>A,p. (Glu13Lys) & \multicolumn{2}{|c|}{ Variant of Uncertain Significance (VUS) } & Heterozygous \\
\hline
\end{tabular}

The distribution of immunohistochemical types among this patients was: $60 \%$ luminal A and $\mathrm{B}, 22.22 \%$ triple negative and $17.78 \%$ Her2 neu amplified.

Surgery was the first treatment for 27 (60\%) patients and $18(40 \%)$ patients underwent neoadjuvant treatment: chemotherapy for 16 patients and anti-estrogenic treatment for 2 patients. Axillary surgery was represented by axillary lymph node dissection in 6 (13.33\%) cases and by sentinel lymph node biopsy in 39 $(86.66 \%)$ cases. $6(13.33 \%)$ cases needed axillary dissection after sentinel lymph node biopsy.

Surgery of the breast was represented in 22
(48.88\%) cases by nipple-sparing mastectomy, $11(24.44 \%)$ cases by skin-sparing mastectomy, $12(26.66 \%)$ cases by skin-reducing mastectomy. Immediate breast reconstruction using alloplastic materials was performed. Direct-toimplant reconstruction was performed in 27 $(60 \%)$ cases. The implant was placed partially under the pectoralis major muscle and covered in the inferior part by synthetic mesh in 6 $(13.33 \%)$ cases, by ADM in $1(2.22 \%)$ case and inferior de-epithelialized skin-flap in $9(20 \%)$ cases. The implant was placed above the major pectoralis muscle in $3(6.66 \%)$ cases, covered by synthetic mesh in $2(4.44 \%)$ cases or $\mathrm{ADM}$ in 2 cases $(4.44 \%)$. B-lite implants 
Figure 3. Bilateral nipple-sparing mastectomy with immediate breast reconstruction with implants (pre and postoperative aspects)

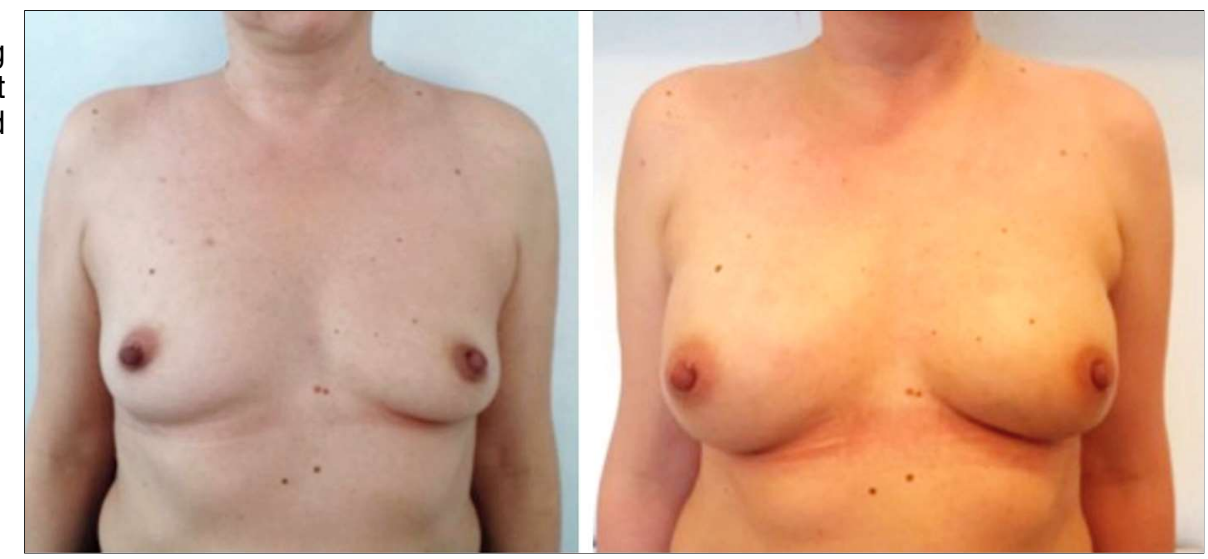

were placed epipectoral in $4(8.88 \%)$ cases. In $26(57.77 \%)$ cases anatomic, textured implants were used and in $1(2.22 \%)$ case the implants were round and smooth. In $1(2.22 \%)$ case a Becker implant was used and it was placed under the major pectoralis muscle. Tissue expanders placed under the major pectoralis muscle were used in $17(37.77 \%)$ cases of 2 -stage breast reconstruction and were later replaced with implants (Figs. 3, 4, 5, 6).

The immediate postoperative complications consisted in: $3(6.66 \%)$ cases of persistent seroma that needed evacuation under ultrasound

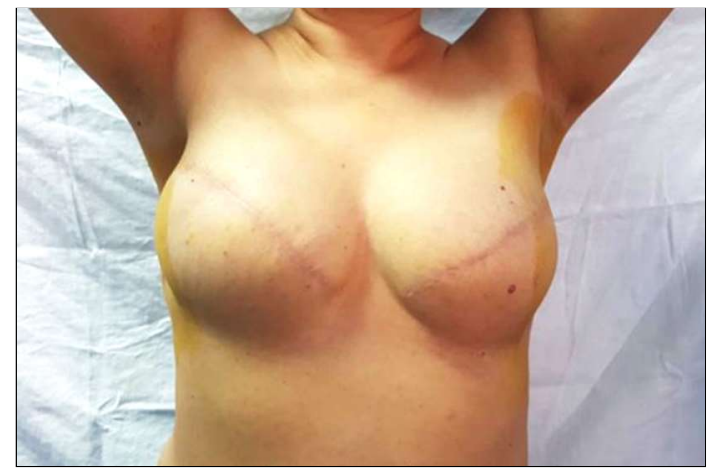

Figure 4. Bilateral skin-sparing mastectomy with immediate breast reconstruction using expanders (4 months postoperative aspect)

Figure 5. Bilateral skin-reducing mastectomy with immediate breast reconstruction with implants placed partially under the pectoralis major muscle and covered by an inferior de-epithelialized skin-flap (pre and postoperative aspect)

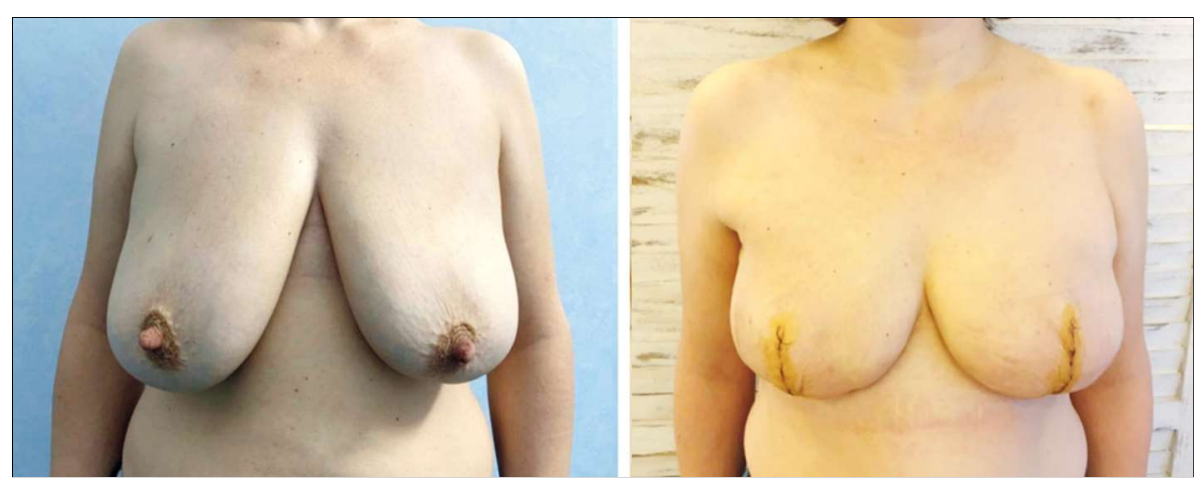

Figure 6. Bilateral nipple-sparing mastectomy with immediate breast reconstruction with B-lite implants (pre and postoperative aspects)

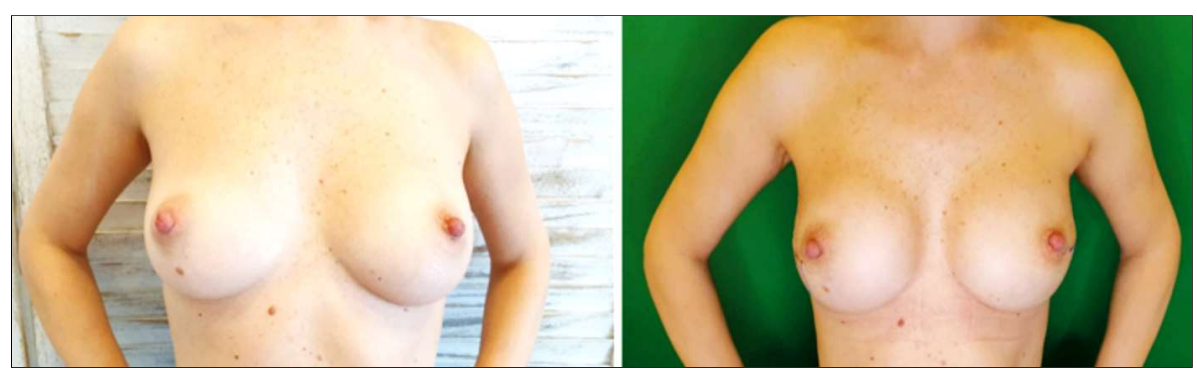


guidance; $2(4.44 \%)$ cases of hematoma treated conservatively, $2(4.44 \%)$ cases of partial necrosis of nipple-areola complex treated conservatively, $1(2.22 \%)$ case of bilateral persistent seroma and partially skin-flap necrosis that needed bilateral implant removal, $1(2.22 \%)$ case of wound dehiscence that led to bilateral implant removal, $1(2.22 \%)$ case of Mondor disease treated medically and 9 (20\%) cases of breast animation.

\section{Discussions}

Breast cancer treatment is in constant progress that leads to survival and quality of life improvement.

Just like a roller coaster, breast cancer surgery had ups and downs in its continuous evolution. If we were to delve in "modern" history, we would find that it begun with W. Halsted and the radical mastectomy that was for fifty years synonymous with breast cancer surgical treatment. After that, different types of modified radical mastectomies were developed, but all of them had the same concept of oncological radicality. Breast cancer conservative treatment was introduced as an alternative to mastectomy in the ' $60 \mathrm{~s}$. Its rates increased gradually due to the change of paradigm that try to explain the biology of breast cancer, development of systemic treatment and radiotherapy and informed decision of the patients (3). Oncoplastic techniques and neoadjuvant treatment lead to the use of breast conserving treatment at a larger scale. Axillary surgery has become selective due to the introduction of sentinel lymph node biopsy technique, thus avoiding unnecessary axillary clearance.

For patients with less advanced breast cancer the first surgical choice is breast conserving treatment, reaching $60-80 \%$ of breast cancer surgeries in the past decade. This type of surgery has the same recurrence and survival rate as mastectomy, but it has the advantages of a beautiful outcome, improving patient's quality of life.

Sometimes, mastectomy is mandatory because of: advanced stages of breast cancer, multifocality/multicenticity, extensive ductal carcinoma "in situ", unfavorable tumor/breast ratio even after neoadjuvant treatment, impossibility of obtaining negative margins, impossibility of postoperative radiotherapy and exceptionally, patient's will.

In the last years, despite an overall trend towards less invasive oncologic surgery it was observed an increased rate of mastectomy, including CPM in patients with unilateral breast cancer.

Also in this study an increase number of patients undergoing CPM was observed with each passing year. In 2020 because of COVID-19 pandemic measures the number of contralateral prophylactic mastectomies was lower.

The proportion of women undergoing CPM increased universally, by $150 \%$ in recent years (4). This increased rates were associated with patient-related factors, rather than tumor biological characteristics (5).

This increasing rate of CPM was unexpected, but explicable. The main reasons are: the increased number of women who undergo genetic testing, the availability of breast reconstruction, use of preoperative breast MRI and improvement of postoperative esthetic results and reimbursement of breast cancer surgeries, overestimation of contralateral breast cancer risk, fear and anxiety (6).

Like in every other domain, even in breast cancer surgery we can discuss about trends and, of course, mentality. Celebrity exposure and publicity have drawn attention to genetic testing of BRCA1 and BRCA 2 mutations and prophylactic surgery (mastectomy, bilateral oophorectomy) in case of pathogenic mutation carriers. The presence of this mutations lead to an important raise of mastectomies, followed by immediate or delayed reconstruction (7).

In this study the number of CPM has increased due to gene testing and improved outcomes of breast reconstruction. CPM was performed for 25 patients with BRCA mutations. The youngest patient was 23 years old, with BRCA1 gene mutation and strong family history.

The average women's breast cancer lifetime 
risk is $12-13 \%$ (8). Women with pathogenic mutation of BRCA genes have a lifetime risk of up to $85 \%$ (8).

A woman with unilateral breast cancer has a higher risk of developing cancer in the other breast. Contralateral breast cancer risk for average-risk women with breast cancer is 0.1 to $0.6 \%$ per year and even though the risk is this low patients tend to overestimated it and choose CPM (8).

Once diagnosed, patients with pathogenic mutation of BRCA genes have a significant risk of developing a contralateral breast cancer of $2-3 \%$ per year. The risk persists for up to 30 years following an initial breast cancer diagnosis (9).

A percent of $0.25 \%$ of the population carry mutated BRCA1 or BRCA 2 genes but approximately $10 \%$ of women diagnosed with breast cancer have a BRCA mutation (8). This means that the risk of breast cancer for a women with pathogenic mutation in BRCA genes is 40 times higher then the general population.

Patients with unilateral breast cancer with pathogenic BRCA1 mutation have a higher risk, 57\%, for contralateral breast cancer compared to BRCA2 pathogenic mutation carriers, $49 \%$ (10).

The risk of breast cancer in women with BRCA mutations is reduced by approximately 90\% when bilateral prophylactic mastectomy is performed (11). So the prophylactic mastectomy is a risk-reduction surgery.

Another indication for CPM in this study was for 3 patients with pathogenic mutation of other genes associated with a high risk of breast cancer (PALB2, CHEK2).

If a woman has a strong family history of breast cancer and pathogenic mutation of BRCA or other genes associated with high risk of breast cancer (CHEK2, PTEN, PALB2, p53, CDH1) CPM may be an option (12).

In this study a CPM was performed for 1 patient with numerous contralateral suspicious foci present on the preoperative magnetic resonance imaging, without any correspondent on ultrasound or mammogram. The postoperative histopathologic examina- tion did not revealed contralateral malignant lesions.

An increasing trend towards CPM was observed in women who underwent preoperative breast MRI, as it can identify occult contralateral carcinoma. Breast MRI was used more and more over the last years and patients that underwent this type of investigation were nearly twice as likely to have CPM (13). The use of breast MRI was associated with increased rates of CPM for women with stage I or II disease (13).

There were 2 patients in this analyze with strong family history, who did not undergo genetic testing and underwent contralateral preventive mastectomy.

In case of women with a significant family history with no proven gene mutation, or in whom genetic testing was not done, the number and degree of relatives with breast and/or ovarian cancer and the age of the patient plays an important role in estimating the risk of contralateral breast cancer (7).

In this study CPM was performed for 1 patient with dense breasts and 1 patient with extended micro-calcifications. Dense breasts are associated with a higher risk of breast cancer. The density of the breasts leads to difficult surveillance, the denser the breast, the harder for imagists to detect the breast cancer. The role of CPM in case of dense breasts or extended micro-calcifications is to limit a difficult and risky breast follow-up (5).

One patient had extreme anxiety related to the risk of contralateral breast cancer, that did not respond to psychological and psychiatric support strategies and CPM was performed. Remission of anxiety and relief was observed after the surgery.

CPM trend is also patient driven. The decision to seek this type of surgery can be determined by an individual's access to information, resources and social networking. Also, factors like ethnicity, level of education and employment may be associated with this decision (2). Peace of mind motivates many patients who choose CPM (14).

Availability of breast reconstruction and good aesthetic results plays an important role 
in the desire for bilateral surgery.

Introduction of reimbursement for reconstructive surgery led to an increased rate of mastectomies followed by breast reconstruction, especially with implants. In USA, Women's Health and Cancer Rights initiated the insurance coverage for reconstructive breast procedures in 1998, in Romania this type of reimbursement started in October 2014, whilst in South Korea, the National Health Insurance program covers the procedures since April 2015.

CPM is more often chosen by breast cancer patients because it reduce the incidence of contralateral breast cancer and may provide a good cosmetic outcome due to the possibility of immediate reconstruction. CPM does not appear to be associated with a survival benefit with the exception of BRCA pathogenic mutation carriers $(1,17)$. Nevertheless, bilateral reconstruction may provide improved cosmetic outcome (8).

For symmetry and risk reduction purposes 11 therapeutic mastectomies with contralateral mastectomy in this study. In the settings of a unilateral breast cancer patient with gigantomastia a therapeutic mastectomy alone can leave the patient with discomfort from chest wall imbalance (1).

Another common reason to choose CPM, usually secondary to avoiding the risk of a contralateral breast cancer, is for breast symmetry. This is a consideration both for those who do or do not want to get a breast reconstruction (18).

The rate of postoperative complications are related to the extent of the surgery. In this study the most frequent immediate postoperative complication was persistent seroma that occurred in $6.66 \%$ of cases. All persistent seroma, but one, were solved conservatively by ultrasound guided aspiration. In the literature the rate of seroma varies between $10.7 \%$ to $20 \%(15,16)$. The main complication was implant loss that occurred in 2 cases that had bilateral persistent seroma and partially skin-flap necrosis. In the literature the rate of implant loss is up to $13 \%$ (16).

Mostly, women base their decision on misperceptions about the benefit of this surgery, not being aware that CPM doubles the risk of surgical complications when compared with unilateral mastectomy and that may lead to the delay of the oncological treatment onset (8).

In this study the mean age of patients was 43.5 years. $64.44 \%$ of patients were pathogenic mutation carriers which explained the early onset of breast cancer. Age is a wellestablished predictor of electing contralateral prophylactic surgery (19).

The risk of developing breast cancer increases with age. The mean age of diagnosis in females with breast cancer is 49.3 years old (20). For women under 40 years, the risk of breast cancer is higher if it is associated with a close family member diagnosed with breast cancer, a close male blood relative with breast cancer or carrier of BRCA gene mutation.

According to TNM classification 13 patients were stage I, 16 stage II, 4 were stage III A and 2 stage III B. This distribution is explained by the fact that CPM was performed in less advanced cases or for responders to neoadjuvant treatment. Prophylactic mastectomy is not recommended for patients with advanced breast cancer that did not respond to neoadjuvant treatment.

In this study the distribution of breast carcinoma patients according to immunohistochemical markers is $60 \%$ luminal A and $\mathrm{B}, 22.22 \%$ triple negative and $17.78 \%$ Her2 neu.

The distribution of immunohistochemical type of breast cancer is: 70\% luminal A and B, $25 \%$ Her2neu and 5\% triple negative (21). The difference is explained by the fact that in this study 26 patients had BRCA pathogenic mutations. Triple negative breast cancers are more common among the BRCA mutation carriers (22).

The main question is when CPM should be indicated or discouraged.

If conserving surgery is safe, there is little or no indication of CPM. It can be taken into consideration when a unilateral breast cancer has indication of mastectomy.

The aims of CPM are: to reduce the 
incidence of contralateral breast cancer, to prevent other surgery, to obtain symmetry and aesthetic result, to diminish cancer related anxiety and to avoid systemic treatment or radiotherapy for a contralateral breast cancer.

There are different predictive factors that drive decision towards CPM: early stage, triple negative cancer, invasive lobular histology, young age, indication of therapeutic mastectomy, previous bilateral prophylactic salpingo-ooforectomy. Also choosing of CPM is a selection bias (8). The patients opting for this type of surgery are more likely to have adequate health insurance, higher socioeconomic status, better access to health care, better general health, early stage tumors and willingness to participate to screening and follow-up (8).

CPM is associated with a lower incidence of contralateral breast cancer in patients with strong family history or genetic mutation but with no favorable impact related on survival. The absolute 20-year survival benefit from CPM is less than $1 \%$ (8). Women with unilateral breast cancer without known familial or genetic risk should not be advised to undergo CPM (8).

Anti-estrogens agents, anti-Her2 agents and chemotherapy reduce the risk of metachronous contralateral breast cancer, but despite the decreasing rates of subsequent contralateral breast cancer this type of surgery is performed at a large scale due to patient's preference $(8,23)$. It does not improve survival and has similar complications rate as therapeutic mastectomy (24).

Women with unilateral breast cancer may desire CPM as a result of concern about the impact of a second breast cancer on prognostic, however this prophylactic surgery reduces the risk of breast cancer in that breast, but does not appear to confer survival benefit (8).

The discussion with the patient it's important for the decision of CPM. The patient must understand that this surgery does not improve survival, nor reduce the risk of recurrence or the need for adjuvant treatments. Contralateral mastectomy is a risk-reduction surgery against the onset of contralateral breast cancer. The risk of complications is higher and because of them postoperative oncological treatments may be delayed. And in addition, several surgeries could be needed. 10\% of women regret their decision to have CPM. In case of immediate breast reconstruction, they have to realize that mastectomy with breast reconstruction does not mean breast augmentation with prosthesis, but a more complex surgery.

A shared decision between surgeon and patient regarding CPM is mandatory.

The American Society of Breast Surgeons elaborated a list of recommendations for CPM in the treatment of breast cancer (25).

CPM should be considered in unilateral breast cancer patients with high risk of developing contralateral breast cancer: positive tests results for BRCA 1 or 2, strong family history in women without genetic testing, young patients with lobular breast cancer and patients with chest radiation before the age of 30 (25).

CPM can be considered for patients presenting a lower risk for contralateral breast cancer: carrier of genes associated with breast cancer risk, such as CHEK-2, PALB2, p53 or strong family history of cancer, but nonBRCA carrier with no known BRCA family member (25).

CPM may be considered for patients with dense breast, microcalcifications, gigantomasty and difficult breast follow-up to limit contralateral breast surveillance, to improve reconstructed breast symmetry, to manage risk aversion and extreme anxiety (25).

CPM should be discouraged for women at high risk of surgical complications, in advanced stages of breast cancer (T4, N3, inflammatory breast cancer), for average risk women with unilateral breast cancer, non-BRCA carriers with a relative tested with BRCA mutation and for male breast cancer, including BRCA carriers (25).

\section{Conclusions}

This study shows an increase in the number of CPM between 2015-2020. The main reasons 
are: genetic testing, availability and reimbursement of breast reconstruction.

The indications for CPM were: pathogenic mutation of BRCA or other genes associated with high risk of breast cancer (PALB2, CHEK2), strong family history for breast cancer, gigantomastia and difficult contralateral breast surveillance.

The patients in this study were younger, with less advanced breast cancer and more frequently triple negative compared to those without indication for prophylactic mastectomy. The rate of immediate postoperative complications was low. CPM is a valid option to reduce the risk of contralateral breast cancer and to achieve a good aesthetic outcome for a selected category of patients with unilateral breast cancer with high risk of contralateral breast cancer.

\section{Conflict of Interest}

The authors declare no conflicts of interests.

\section{Ethics of Approval}

All procedures involving human participants were in accordance with the ethical standards of the 1964 Helsinki Declaration and its later amendments.

\section{References}

1. Newman LA. Risk-Reducing Mastectomy: who is a candidate and what are the outcomes? Springer, 19 May 2013. Current Breast Cancer Reports. 2013:5:73-85.

2. O'Donnell Maureen, Estimating contralateral breast cancer risk. Springer, 16 May 2018. Current Breast Cancer Reports. 2013;10: 91-97.

3. Coebergh JW. Early breast cancer in Europe: progres and pitfalls in detection and management at the start of the new century. Eur $\mathrm{J}$ Cancer. 2003;39(12):1645-7.

4. Ranchod $Y$. What is the link between age and breast cancer? Medical News Today, July 3, 2019

5. Yao K, Stewart AK, Winchester DJ, Winchester DP. Trends in contralateralprophylactic mastectomy for unilateral cancer: a report from the National Cancer Data Base, 1998-2007. Ann Surg Oncol. 2010;17(10):2554-62.

6. Sisco M, Du H, Warner JP, Howard MA, Winchester DP, Yao K. Have we expanded the equitable delivery of postmastectomy breast reconstruction in the new millennium?, Evidence from the national cancer database. J Am Coll Surg. 2012;215(5):658-66.

7. Gareth E, Wisely J, Clancy T, Lalloo F, Wilson M, Johnson R, et al.
Longer term effects of the Angelina Jolie effect: increased risk-reducing mastectomy rates in BRCA carriers and other high-risk women. Breast Cancer Res. 2015;17:143.

8. Boughey JC, Attai DJ, Chen SL, Cody HS, Dietz JR, Feldman SM, et al. Contralateral Prophylactic Mastectomy (CPM) Consensus Statement from the American Society of Breast Surgeons: Data on CPM Outcomes and Risks. Ann Surg Oncol. 2016;23(10):3100-5.

9. Nath Basu N, Evans G. Risk of contralateral breast cancer amongst BRCA1/2 mutation carriers. Transl Cancer Res. 2016;5(Suppl 6): S1066S1069.

10. Biglia N, D'Alonzo M, Sgro L, Tomasi Cont N, Bounous V, Robba E. Breast cancer treatment in mutation carriers - surgical treatment. Minerva Ginecol. 2016;68(5):548-56

11. Timothy R, Friebel T, Lynch HT, Neuhausen SL, van 't Veer L, Garber JE, et al. Bilateral prophylactic mastectomy reduces breast cancer risk in BRCA1 and BRCA2 mutation carriers: the PROSE Study Group. J Clin Oncol. 2004; 22(6):1055-62

12. Guillem JG, Wood WC, Moley JF, Berchuck A, Karlan BY, Mutch DG, et al. ASCO/SSO review of current role of risk-reducing surgery in common hereditary cancer syndromes. J Clin Oncol. 2006;24(28): 4642-60.

13. Sorbero MES, Dick AW, Beckjord EB, Ahrendt G. Diagnostic breast magnetic resonance imaging and contralateral prophylactic mastectomy. Ann Surg Oncol. 2009;16(6):1597-605.

14. Jagsi R, Hawley ST, Griffith KA, Janz NK, Kurian AW, Ward KC, et al. Contralateral Prophylactic Mastectomy Decisions in a Population-Based Sample of Patients with Early-Stage Breast Cancer. JAMA Surg. 2017; 152(3):274-282.

15. Boughey JC, Hoskin TL, Hartmann LC, Johnson JL, Jacobson SR, Degnim AC, et al. Impact of reconstruction and reoperation on long-term patient-reported satisfaction after contralateral prophylactic mastectomy. Ann Surg Oncol. 2015;22(2):401-8. Epub 2014 Sep 6.

16. Scheepens Josien CC, van 't Veer L, Esserman L, Belkora J, Mukhtar RA. Contralateral prophylactic mastectomy: A narrative review of the evidence and acceptability. Epub 2021 Feb 10.

17. Yanko-Arzi R, Cohen MJ, Braunstein R, Kaliner E, Neuman R, Brezis M. Breast reconstruction: complication rate and tissue expander type. Aesthetic Plast Surg. 2009:33(4):489-96. Epub 2008 Jun 6.

18. Lam TC, Hsieh F, Salinas J, Boyages J. Immediate and Long-term Complications of Direct-to-implant Breast Reconstruction after Nipple - or Skin-sparing Mastectomy. Plast Reconstr Surg Glob Open. 2018;6(11): e1977. eCollection 2018 Nov.

19. Elsayegh N, Webster RD, Gutierrez Barrera AM, Lin H, Kuerer HM, Litton JK, et al. Contralateral prophylactic mastectomy rate and predictive factors among patients with breast cancer who underwent multigene panel testing for hereditary cancer. Cancer Med. 2018;7(6):2718-2726.

20. Hajizadeh E, Abdollahi M, Baghestani AR, Haghighat S, ORCID. Prognostic cut point for breast cancer age of diagnosis. Internat J Cancer Manag. 2018:11(5);e9291.

21. Chand P, Garg A, Singla V, Rani N. Evaluation of immuno-histochemical profile of breast cancer for prognostics and therapeutic Use. Niger J Surg. 2018;24(2):100-106.

22. Chen H, Wu J, Zhang Z, Tang Y, Li X, Liu S, et al. Association between BRCA status and triple-negative breast cancer: a meta-analysis. Front Pharmacol. 2018:9:909.

23. Bertelsen L, Early Breast Cancer Trialists' Collaborative Group. Effects of chemotherapy and hormonal therapy for early breast cancer on recurrence and 15-year survival: an overview of the randomised trials. Lancet. 2005;365(9472):1687-717.

24. Spillane AJ, What is new in the surgical management and prevention of breast cancer? Med J Aust. 2016;204(8):311-4

25. Boughey Judy C, Attai DJ, Chen SL, Cody HS, Dietz JR, Feldman SM, et al. Contralateral prophylactic mastectomy (CPM) consensus statement from the American Society of Breast Surgeons: Data on CPM Outcomes and Risks. Jul 28, 2016. Ann Surg Oncol. 2016; 23(10):3100-5. 